DOI: http://dx.doi.org/10.18569/tempus.v13i2.2659

\title{
Questões atuais sobre direito constitucional à saúde
}

\section{Current issues in constitutional health care law}

\section{Questions d'actualite constitutionnel a la sante} sur

Marta Cerioni

RESUMO: O ensaio lida com questões atuais na lei constitucional de saúde. Após uma visão reconstrutiva da estrutura da lei, a contribuição trata da dimensão subjetiva, considerando quem tem direito a benefícios em um momento histórico em que o Estado italiano se tornou uma nação de intensa imigração. A segunda questão trata do perfil da saúde coletiva, a saber, a reintrodução da obrigação de vacinação, enquanto a terceira trata da dificuldade de financiar todas as atividades do serviço público de saúde com recursos públicos. O debate jurídico que está ocorrendo na Itália, com base nas indicações de especialistas em direito e na jurisprudência do Tribunal Constitucional, é muito útil para todos os países de língua românica porque os princípios jurídicos que resultam dele também podem ser usado em outros países da América Latina e da Europa Latina.

Palavras chave:lei individual. direito coletivo.Imigração.Vacinas. crise econômica.

ABSTRACT: The essay deals with current issues in constitutional health care law. After a reconstructive overview of the structure of the law, the contribution deals with the subjective dimension, considering who is entitled to benefits at a historic moment in which the Italian state has become a nation of intense immigration. The second issue deals with the profile of collective health, namely the reintroduction of the vaccination obligation, while the third deals with the difficulty of financing all the activities of the public health service with public resources. The legal debate that is taking place in Italy, on the basis of the indications of experts in law and the jurisprudence of the Constitutional Court, is very useful for all the Romance language countries because the legal principles that result from it can also be used in other countriesin Latin America and Latin Europe. Keywords: individual law. collective law. Immigration. Vaccines. economic crisis. 
RESUMEN: El ensayo trata sobre temas actuales en la ley de salud constitucional. Después de una visión general reconstructiva de la estructura de la ley, la contribución se relaciona con la dimensión subjetiva, considerando quién tiene derecho a los beneficios en un momento histórico en el que el estado italiano se ha convertido en una nación de inmigración intensa. El segundo tema trata sobre el perfil de salud colectiva, a saber, la reintroducción de la obligación de vacunación, mientras que el tercero trata sobre la dificultad de financiar todas las actividades del servicio de salud pública con recursos públicos. El debate legal que se está llevando a cabo en Italia, sobre la base de las indicaciones de expertos en derecho y la jurisprudencia del Tribunal Constitucional, es muy útil para todos los países de lengua románica porque los principios legales que resultan de él también pueden ser útiles. Utilizado en otros países de Latinoamérica y Europa latina.

Palabras clave:ley individual.derechocolectivo.inmigración.Vacunas.crisis económica.

\section{THE EVOLUTION OF CONSTITUTIONAL HEALTH CARE LAW: A COMPLEX AND FLEXIBLE RIGHT}

The right to health is expressly qualified by our Constitution as a "fundamental right" and as such it is ascribed the characteristics of primary, absolute law, owed ergaomnes and applicable immediately in the relations between private individuals from the civil point of view ${ }^{1}$, as well as being inalienable, nontransferable (except for the deeds of disposal of one's own body pursuant to Article 5 of the Civil Code) $)^{2}$. Moreover, the link between the right to health and the realization of the freedom and equality of individuals emerged from the report of the Constituent Assembly which discussed Art. 26 of the Project ${ }^{3}$. Essential to the right to health is the establishment of a national health service that promotes its implementation. Forty years after the approval of the law establishing the National Health Service (SNN 1. n. 833 of 1978), it is possible to affirm - looking at the phenomenon from afar - that the Republic overcame the doubts advanced by the Hon Nitti in 1947 when commenting that the draft constitution on health protection was too ambitious and could not be guaranteed by the State. The Hon Nitti said that «The Republic sprotects health, promotes hygiene and guarantees free treatment to the needy'. So, the Republic, as of now, takes on the obligation to protect health, promote hygiene and ensure free care for the needy. I want to repeat it because I do not believe my eyes. You know what the situation in Italy is, you know what hospitals are [...]. And now we suddenly make the commitment to guarantee all these things that we will not be able to provide for several years to come? Now do you think it is a good procedure to promise in the name of the Republic what cannot be maintained? [...] They are blank promissory notes that are to be issued on behalf of the Republic ${ }^{4}$.

On the contrary, looking more closely at the current state of the Italian health system, it is still possible to find gaps in protection and non-implementations. Worsening the condition, there has been the economic-financial crisis which has led successive governments to enact various legislative measures aimed at restricting financing to the sector. A case in point could be the repayment plans for regions with health care expenditure deficits or the closing of annual budgets in

Tempus, actas de saúde colet, Brasília, 13(2), 129-141, jun, 2019. ISSN 1982-8829 
August / September and the consequent postponement of services until the month of January of the following year. The right to health in Italy is facing important and extremely complex challenges. We will now look at three issues discussed in the Italian system whose solutions, presented in terms of legal principles, can also be useful to other Romance-language countries that are in the same conditions.

\section{DISCUSSION OF SOME PROFILES:}

\section{a) The subjective scope of application to the issue of immigration}

Article 32 of the Italian Constitution provides for "free" treatments for the indigent. This concept should not be interpreted as absolute poverty or lack of means of support, but rather in relative terms or as "medical indigence" in the sense of the objective impossibility of autonomously paying for burdensome but indispensable therapies for survival. Two judgments of the Constitutional Court have introduced the relativity of this concept: sentence n. 185 of 1998 and n. 309 of 1999.

The right to health, moreover, is attributed not to the citizen but to the individual without distinction between those who do not have Italian citizenship and those that do.

In a moment of economic difficulty for the Italian State, where the health sector is increasingly subjected to a reduction in resources, a hot topic is represented by the lack of charges for health care for foreign citizens living in Italy for various reasons. No problems are found for the citizens of the European Union who enjoy the benefits of the European Health Insurance Card (EHIC), provided for by EU Regulation no. 631/2004 in cases of temporary residence (up to three months), thanks to which all the medically necessary treatment is provided ${ }^{5}$.

A different regulation applies, instead, to citizens of countries not belonging to the European Union.

In the Italian legal system this is indicated by the Consolidation Act on Immigration (TUI, Legislative Decree No. 286 of 1998) within the general principles of the Italian Constitution.

The Constitution establishes, in fact, a law on the condition of the foreigner, obliging the legislator to respect not only the fundamental human rights (article 2) and customary international law (article 10, paragraph 1), but also "international norms and treaties" (Article 10, paragraph 2).

Article 34 of the TUI provides for three different categories. It gives the foreigner regularly residing in Italy with an up-to-date or pending renewal long-term residence permit (for example, for work reasons) the rights and duties of the Italian citizen, including the obligation to register themselves and their dependents with the National Health Service .

Regular residents who do not fall into these categories have the obligation to take out health

ISSN 1982-8829 Tempus, actas de saúde colet, Brasília, 13(2), 129-141, jun, 2019. 
insurance or, alternatively, to register with the NHS paying an annual contribution.

For holders of residence permits for study purposes (or au pairs) the enrolment is instead at one's discretion.

It can be said that the regular foreigner is guaranteed a protection substantially homogeneous to that of citizens.

On the contrary, art. 35 paragraph 3 of the TUI provisions guarantees that illegal immigrantsare only "ensured, in public and accredited surgeries and hospitals, treatment which is urgent or otherwise essential, even if continuous, due to illness and accident and the preventive medicine programs which are extended to safeguard individual and collective health". Some services which are unconditionally guaranteed include: safeguarding of pregnancy and maternity, protection of children's health, vaccinations, interventions of international prevention and interventions related to infectious diseases.

The choice made by the legislator has been criticized by some political parties and many experts on legal matters as being too restrictive.

According to some authors it is "of dubious legitimacy" because it is not justified by financial reasons. The foreigner contributes to the financing of public spending at least through indirect taxes. It seems not to be justified even by the absence of a "bond" of integration with the state because the relationship with the territory is created regardless of the regularity or otherwise of the stay.

Moreover, the legislation has been criticized because of the precarious state of health in which many immigrants find themselves, which would suggest that there should be the opportunity to offer wider access to medical care for the purposes of human solidarity referred to in Article 2 of the Constitution.

Finally, it has been condemned even for financial reasons. If the state does not guarantee the treatment of diseases, these are aggravated or become chronic and subsequently impose a higher cost on the national health service. In fact, the constitutional jurisprudence, beginning with sentence n. 120 of 1967 , has constantly reaffirmed that all the subjects present on the national territory, regardless of the regularity or otherwise of their situation with respect to the rules on access to and permanence in the territory, must be granted the fundamental rights provided by the rules of domestic law, international conventions in force and generally recognized principles of international law (like, for example, Court of Justice Judgment No. 203/1997, No. 252/2001, No. 432/2005, No. 324 / 2006 and No. 148/2008).Therefore, in the case of urgency or threat to life, the State will be obliged by the Constitution and by the international treaties of which it is part to intervene with costs higher than those that it could previously have sustained.

\section{b) The collective dimension of health: the reintroduction of the vaccination obligation}

Tempus, actas de saúde colet, Brasília, 13(2), 129-141, jun, 2019. ISSN 1982-8829 
Another extremely controversial issue concerns the right to refuse treatment in the context of the right to health as a collective right. The situation is more complicated because the provision of the service takes place with the aim of preserving the health of the community by preventing the potential spread of diseases and other consequences that can be undergone by third parties due to an individual's illness. In such cases, it is possible to impose the treatment against the will of the subject.

Beginning with sentence no. 307 of 1990 the Constitutional Court has commented on this provision because it is mandatory to "preserve the state of health of others, since it is precisely this further purpose, concerning the health of the community, which justifies the restriction of the fundamental right of each person to their own health". Among the various mandatory health treatments in Italy, there is legislation that provides for the obligation of vaccination for newborns provided for by the Decree Law n. 73/2017 converted with changes into Law n. 119/2017 in order to guarantee good epidemiological safety conditions at a time when dormant diseases are reemerging.

In the last few years socalled "no-vax" movements have emerged, run by citizens that are contrary to the administration of vaccines because they believe that they are the cause of the onset of autism in children.

Despite the success of the 2005-2007 vaccination scheme, essentially due to the good vaccination coverage at that time, there has recently been a resurgence of infectious diseases. The State has proceeded to reintroduce some mandatory vaccinations on the national territory with the DecreeLaw 73/2017, containing "Urgent provisions concerning vaccination prevention", then converted into law with modifications in Law 119/2017.

The vaccination legislation includes ten mandatory vaccinations for children up to sixteen years of age and it provides for the exemption from one or more of these vaccinations due to immunization following a natural disease and the possibility of omitting or postponing vaccinations in the case of an established health hazard.

In the hypothesis of non-compliance with the vaccination obligation, parents and legal guardians may be subjected to a pecuniary administrative sanction ranging from one hundred to five hundred euros; however, they will not incur this sanction if they carry out the vaccinations after being challenged by the local health authority with territorial jurisdiction. In the event of failure to comply with the vaccination obligation, before sanctions are imposed, the modified law includes a further commendable step: the convocation of the child's parents, legal guardians or foster parents to the local authority health care establishment for an interview in order to provide further information on vaccinations and to request that they be carried out.

The fulfillment of the vaccination obligations according to the modalities foreseen by the law

ISSN 1982-8829 Tempus, actas de saúde colet, Brasília, 13(2), 129-141, jun, 2019. 
decree was a requirement for access to educational services for early infancy and nursery schools, including unaccredited private kindergartens, but not for other levels of education.

This distinction between optional nursery schools and compulsory primary and secondary schools also remains in the converted law and seems to reconcile two different interests: the right to health referred to in article 32 of the Constitution - connected to the duties of political, economic and social solidarity pursuant to article 2 of the Constitution - and the right to education and compulsory schooling as per articles 33 and 34 of the Constitution, which guarantee a "minimum level of education, below which it is presumed that the individual is not in a position to participate in the political, economic and social organization of the country» ${ }^{6}$.

The decree-law was challenged before the Constitutional Court by the Veneto Region. With sentence n. 5 of 2018, the Constitutional Court declared the issue unfounded and kept the law in force.

Beyond the concrete issues, what matters are the principles of law that can be applied in many states.

In conclusion, the individual right to health may undergo restrictions - in particular through mandatory health care interventions - provided that they are not aimed at improving the health of the individual or pursuing a generic public interest, but rather at protecting the specific interests of the health of the community.

It is, therefore, possible to provide for mandatory medical treatments, provided they meet certain conditions.

a. First of all, "a health treatment can be imposed only if it does not negatively affect the health of the person who undergoes it, except for those consequences which, due to their temporary and minor nature, appear normal for any health intervention, and therefore tolerable"'

b. The intensity of the obligatory intervention that limits the individual's freedom of self-determination in health matters must be proportionate to the needs of the health of the community, "according to a proportionality relationship that results in a balanced judgment between values".

c. Finally, the balance between the individual and the collective dimensions of health implies that, where damage to the health of the individual due to undergoing compulsory medical treatment occurs, the right to compensation for the damage is recognized by the community and, therefore, by the State that ordered the obligatory health treatment ${ }^{8}$.

c) The dimension of the right to health as a financially conditioned law: the financial

Tempus, actas de saúde colet, Brasília, 13(2), 129-141, jun, 2019. ISSN 1982-8829 


\section{sustainability of the public national health system}

Traditional legal doctrine considers the right to health among the "financially conditioned" rights $^{9}$ or those rights whose effectiveness is subordinated to the resources made available to the State because they are "expensive" rights.

The jurisprudence of the Constitutional Court has already studied this issue with sentence no. 455 of $1990^{10}$. This regarded the legitimacy of a provision of the Autonomous Province of Trento concerning the health services available to non self-sufficientelderly people who were hospitalized in nursing homes. The law provided for a maximum spending limit for each patient. The Court used this case to establish that the right to health is a primary and fundamental right, which every person can ask a judge to enforce. In other words, the right to health can be invoked as an absolute right.

However, the interesting point is that, if a specific health treatment is requested invoking the right to health, it can be subject to conditions. The right to "health treatment" - which is a part of the right to health - "is subject to the determination of the instruments, timing and methods of implementation of the relative protection by the ordinary legislator". It is a "right to positive benefits", based on "constitutional rules of a programmatic nature imposing a certain end to be achieved" 11 .

Therefore, the part of the right to health that concerns the right to health care is "conditioned" by the legislative action that: a) balances the law with other constitutional rights and b) "takes into account the objective limits that the legislator encounters in its implementation in relation to the organizational and financial resources available at the time "12.

Many experts in legal doctrine have noted that the two factors a) and b) are not in an equal position but in a subordinate one. That is, the resources are allocated after the legislator has assessed the balancing of constitutional rights: the decisions about how to finance the various rights with the resources available depend on the balancing and evaluation of these rights. Therefore, the scarcity of resources is consequential to factor a $)^{13}$.

This method of allocating resources is indicated through the concept of gradualness: that is, one has the right to access health services after balancing with other constitutional values and even after a legislative assessment of the resources available.

Subsequently, the concrete cases submitted to the judgment of the Constitutional Court have allowed the change from the autonomous judgment of gradualism to the judgment of reasonableness ${ }^{14}$ since the latter considers the condition in a global situation of interpretation of constitutional values.

Another decision that allows us to trace an evolutionary jurisprudential path in this issue is

ISSN 1982-8829 Tempus, actas de saúde colet, Brasília, 13(2), 129-141, jun, 2019. 
legislation n. 304 of $1994^{15}$ which stresses that the protection of the right to health is conditioned by a number of factors which the legislator must take into account. According to the Court, the regulation provided for by article 32 of the Constitution is a programmatic provision, or a rule that affirms a right but does not explain how to protect it. For this last aspect, the protection is entrusted to the ordinary legislator who, with primary and secondary rules, should implement the law. The implementation activity, therefore, is subjected to multiple factors both of balancing with other values and of an economic nature.

The most important point is that in which the Court specifies that under no circumstances can financial reasons infringe on the right to health so much that "the essential heart of the right $[. .$. connected to the inviolable dignity of the human person" is annulled ${ }^{16}$. In this case, the legislator would exercise their own legislative discretion unreasonably.

Jurisprudence, therefore, has established what the "irreducible core" of the right to health is. Sentence n. 309 of 1999, on the reimbursement of health expenses incurred abroad, indicates the underlying principle to be followed, that is the protection of health where the dignity of the person is at stake, as indicated in Article 2 of the Constitution. ${ }^{17}$

The constitutional reform of 2001 also introduced a specific competency of the state legislator when it deals with "essential levels of benefits with respect to civil and social rights that must be guaranteed throughout the national territory". Considering that the health organization is the responsibility of the Regions, the aforementioned clause allows the central State to guarantee uniform performances that cannot be restricted by the individual Regions and their implementation policies or by individual regional budgets. The positive consequences of the jurisprudence of the Constitutional Court have, in fact, allowed for the setting of minimum limits for health protection.

It is, indeed, a ruling by the Constitutional Court which seems to have introduced a specific competence of exclusive state legislative activity: "the protection of essential levels of performance in times of crisis". Letter m) of Article 117 of the Constitution, in fact, does not allow the State to regulate entire material sectors and the jurisprudence of the Court has settled on an interpretation of this concept of legitimacy in terms of "setting the structural and qualitative levels of benefits". In other words, this legislation conferring jurisdiction to the State should be invoked only in relation to the determination, by state laws, of the essential level of provision of specific services. The Council, in this case, deviates from its traditional interpretive path because if the contested rules aim to protect citizens from the impossibility of meeting basic needs, attributable to the concept of dignity, it is precisely the constitutional rules of articles 2 and 3 of the Constitution which also impose the "allowance for and direct provision of certain measures, as well as the setting of the structural and qualitative level of a given service".

The ruling creates a link between the principle of substantial equality and the concept of "essential content" in letter $\mathrm{m}$ ) of article 117 of the Constitution which does not represent a novelty 
for modern constitutionalism. Broad foundations can be found in the German constitutional jurisprudence and in the Wesensgehalt theory on which various interpretations have been made, from absolutist positions (according to which the essential core of every right would be definable a priori and represents an inviolable limitation of the legislator) to relativistic ones (according to which the essential content constitutes a reasonable balance between the value of the law, its limits and other values).

First of all, the word "essential" indicates the area of what is "constitutionally obligatory". Some experts have discussed this issue and concluded that the quantum of the content of the rights referred to in letter $\mathrm{m}$ ) is equivalent to that which Part I of the Constitution states is guaranteed to each person. Other scholars, however, have found that the level referred to in letter $\mathrm{m}$ ) indicates a different concept to that contained in Part I of the Constitution, and in particular a wider degree of protection than that which would be guaranteed under Article 3 of the Constitution. The sentence under discussion seems to strengthen the connection between letter m) of article 117 of the Constitution and the principle of substantial equality, but the two concepts do not seem to coincide, since the notion of competence is extended thanks to the invocation of the principle of substantial equality to which, clearly, a wider sphere of operation is to be attributed because it is a norm derived from a principle which can in turn be reconstructed as a value.

In any case, the most striking novelty of the sentence is the exceptionality of the economic crisis (letter a) which allows the Court to differentiate the case in question with respect to precedents similarly subjected to fixed funding in the field of social assistance.

\section{BY WAY OF CONCLUSION: THE PRINCIPLE OF CONSTITUTIONALLY ORIENTED UNIVERSALISM}

Finally, we cannot be silent about the fact that the Beveridge model of universalism is facing a very serious challenge because of the level of public sustainability that has come to undermine its foundations and, in particular, the gratuitousness of all treatments. As a matter of fact, article 32 of the Constitution reserves the gratuitousness of care only for the indigent. It was only with law n. 833/1978 that the principle of free health care became extended to all and this is ensured by the ordinary legislation followed by an organization of facilities and skills, as well as organic, administrative and financial resources such as to make this principle operative and effective. Without adequate legislation that guarantees sufficient funding, universalism would be just an empty word. It is precisely for this reason that, given the wording of the constitution and the objective data regarding the lack of sufficient funding, some theses have emerged in doctrine which emphasize that the gratuitousness of care should only be granted to the indigent ${ }^{18}$. From the point of view of a constitutional interpretation they are correct.

Nonetheless, it is possible to plead that the principle of universalism in the health sector can derive directly not from art. 32 of the Constitution but from the combined arrangement of articles

ISSN 1982-8829 Tempus, actas de saúde colet, Brasília, 13(2), 129-141, jun, 2019. 
2 and 3 of the Constitution, which establishes the inviolability of human rights (including the right to health), the equal dignity of citizens and the removal of obstacles (including economic ones) that prevent the full realization of the human person (including the removal of those high costs that could be imposed on people for access to care).

This approach, therefore, obliges the organs of the Republic to instigate first of all the regulatory and administrative changes that would allow the reduction of waste and avoid a spate of cuts in health services. In the final analysis, the measures to grant free treatment only to the needy for budgetary reasons should be subsidiary and implemented only after serious reform and they should undergo a close scrutiny of constitutionality.

In sentence no. $275 / 2016$ the Constitutional Court seems to have opened a breach in this direction when it strongly affirms that it is not possible to accept the thesis that "any right, even non-restrictable ones [...], must always be subject to a screening of sustainability within the overall framework of resources available. [...] It is the guarantee of the non-restrictable rights that affects the budget, and not the balance of this that conditions the appropriate disbursement"19.

This does not mean that it is constitutionally forbidden to finance some benefits with the contribution of those who have a capacity to pay but this point must be provided for in the law by the principle of legality ${ }^{20}$. Consequently, it is the legislative instrument which, by reconciling opposing interests, should firstly deal with a new reallocation of the system (including the financing system) and, secondly, in extrema ratioprovide for forms of user contributions. As a further guarantee of the non-restrictable minimum level of law, there is always the control of the Constitutional Court that can review both the law in question and the budget laws ${ }^{21}$.

The case of the British National Health Service is emblematic and instructive for Italy because it highlights how the allocation of financial resources predominantly for urgent health care is not an optimal choice because it intervenes exclusively at the final level (with higher costs) without an adequate preceding support network that would be more expensive but would create more savings in the medium and long term.

At this historical juncture, it seems, therefore, that the principle of public sustainability has eroded that of universalism in health care, as shown by the data regarding the decrease in capital expenditure by one third compared to the European average, the increase in out-of-pocket spending, the increase in voluntary insurance policies, and the move towards corporate welfare schemes that provide coverage of health expenditure (therefore a sort of coverage based on merit) ${ }^{22}$.

This has happened mainly because there has not been a proper reorganization of the Italian health service which could deal with health care as a whole and transform the principle of universalism tout court into a constitutionally oriented universalism ${ }^{23}$ which, attentive to budgetary needs, does not give all the cures free of charge to everyone. Instead, on the basis of the combined disposition 
of articles 2 and 3 of the Constitution, the system must be measured against the possibilities of each individual which have been concretely verified, after the legislative interventions for the overall adjustment of the national health service to the new needs of the Italian population.

Just as it is true, as the Court maintains, that the certainty of funding is the cause of the effectiveness of $\mathrm{law}^{24}$, it is also true that the effectiveness of a right is pursued by farreaching and systemic regulatory measures that prevent social Darwinism ${ }^{25}$ with its prevalence of the strongestover the weakest, the most astute over the most naive, the most gifted over the least capable.

\section{REFERENCES}

1 See Court Cassazione sez. un., no., n. 796/1973.

2 Luciani M. Il diritto costituzionale alla salute. Diritto e società. 1980; Montruschi L. Articolo 32. Commentario della Costituzione. Rapporti etico-sociali. Bologna-Roma, 1976; Smuraglia C. Salute. Tutela della salute. Enc. Giur. Treccani. Roma,1989; p.1.

3 Simoncini A., Longo E., Articolo 32. Commentario alla Costituzione. Milano. 2006.

$4 \quad$ Nitti F.S. 19 aprile 1947.A.C. II. 1034.

5 Moreover, the EU directive 2011/24/EU (art.3,lett.c) concerning cross-border health care allows for the concept of affiliation of a European citizen in a member state: health care must be provided by the host country to anyone moving legally within the European Union. See CONSITO M.Gli stranieri di fronte al diritto alla salute e all'assistenza. In: Giorgis A.,Grosso E., Losana M. editor.Diritti uguali per tutti? Gli stranieri e la garanzia dell'uguaglianza formale. Milano: 2017, 166-168. Costamagna F.I servizi socio-sanitari nel mercato interno europeo.L'applicazione delle norme dell'Unione europea in materia di concorrenza, aiuti di Stato e libera circolazionedei servizi, Napoli: 2011. Innocenti E.La portabilità del diritto all'assistenza sanitaria tra deterritorializzazionee solidarietà. Roma: 2015.

6 Camerlengo Q.Articolo 34.In: Bartole S., Bin R. Commentario breve alla Costituzione Padova, Cedam: 2008, p. 342.

7 Corte cost., sent. 307/1990, pt. 2 cons. dir.; Corte cost., sent. 5/2018, pt.8.2.1 cons. dir.

8 Così Corte cost., sent. 307/1990, pt. 2 cons. dir.

$9 \quad$ Merusi F.. Servizi pubblici instabili. Bologna. 1990, 30.

10 See www. giurcost.it

11 Par. 3 cons. in diritto di sent. 455 del 1990.

ISSN 1982-8829 Tempus, actas de saúde colet, Brasília, 13(2), 129-141, jun, 2019. 
12 Par. 3 cons. in diritto di sent. 455 del 1990.

13 Salazar defines the scarcity of resources as "an objective unchangeable fact which remains outside the balancing" Salazar C., Crisi economica e diritti fondamentali, relazione al Convegno AIC, 9 .

14 Cavasino E. La flessibilità del diritto alla salute. Napoli, 2012, 89 ss.

15 Rovagnati A. La pretesa di ricevere prestazioni sanitarie nell'ordinamento costituzionale repubblicano.In: Cavasino E., Scala G., Verde G. (editor), I diritti sociali dal riconoscimento alla garanzia, Napoli, 2013, 178 ss.

16 Punto 5 del considerato in diritto sent. corte cost. 304/1994.

17 Principato L. Il diritto costituzionale alla salute: molteplici facoltà più o meno disponibili da parte del legislatore o differenti situazioni giuridiche soggettive? In: Giurisprudenza costituzionale, 4, 1999, 2508 ss.

18 For a general analysis of the various positions, see ex multis, BALDUZzI R., Livelli essenziali e risorse disponibili: la sanità come paradigma.In: Roversi MonACO F., BotTARIC. (editor), La tutela della salute tra garanzie degli utenti ed esigenze di bilancio, Rimini, 2012, 79 ss; BIfULco D., L'inviolabilità dei diritti sociali, Napoli, 2003, 20; Ciolli I. Crisi economica e vincoli di bilancio. In: Aa. Vv. La Costituzione alla prova della crisi finanziaria mondiale. Atti delle V giornate italoispano-brasiliane di diritto costituzionale. Lecce, 14-15 settembre 2012.In www.gruppodipisa. it.Colapietro C. La giurisprudenza costituzionale nella crisi dello Stato sociale. Padova. 1996. GambinoS. (editor), Diritti sociali e crisi economica. Problemi e prospettive, Torino, 2015; PInELLI C., Sui livelli essenziali delle prestazioni concernenti i diritti civili e sociali (art. 117, comma 2, lett. m), Cost.).In Dir. pubbl.2002, 887 ss.; TRUCCO L. Livelli essenziali delle prestazioni e sostenibilità finanziaria dei diritti sociali.In: www.gruppodipisa.it, 2012.

19 Points 7 and 11 of Cons. in dir.

20 Points 15 of Cons. in dir.

21 See the article by Longo E.Una concezione del bilancio costituzionalmente orientata: prime riflessioni sulla sentenza della Corte costituzionale n. 275 del 2016.In Federalismi, n. 10/2017 in which he affirms that "the spirit of the reform seems to a certain extent to have been overturned: assuming from the axiological point of view that the rights, or rather their inviolable core, have priority with respect to the needs of the budget, then legislation for concrete action must be implemented, or in other words the budget planning must be carried out in such a way that resources are dedicated primarily to the protection of those fundamental rights.” (p. 11). 
$141 / /$

22 Pavolini E., Ascoli U., Arlotti M. Une transformation structurelle en cours dans le systeme de santé italien: les fonds de santé, Relation at Congress "Systèmes de santé: complexité et nouveaux défis”'23 juin 2017 Università Politecnica delle Marche. SeeSpandonaro F.(editor), Il Rapporto Sanità, L'Universalismo Diseguale, In: www.creasanita.it orRapporto Sanità, Il cambiamento della Sanità in Italia fra transizione e deriva del sistema.

23 Marmot M. La salute diseguale. La sfida di un mondo ingiusto.Roma 2016.

24 Points 6 and 7 ofCons. in dir.

25 Bonazzi T. Darwinismo sociale.In: Enciclopedia delle scienze sociali. vol. II, Roma, Istituto della Enciclopedia Italiana. 1992, pp. 674-683. SeeLa Vergata A. Positivismo e darwinismo sociale. In: Il pensiero politico. Idee teorie dottrine. vol. III, Ottocento e Novecento, editor Pasquino G. vol. I, Torino, Utet, 1999, 243-272.

Artigo apresentado em:dezembro 2018

Artigo aprovado em:março 2019 Conflito de interesses:a autora declara não haver conflito de interesses Suporte financeiro: não 